\title{
IMPLICATION OF OWNERSHIP STRUCTURE OF DIVIDEND POLICY AND COMPANY VALUE
}

\author{
Misrah \\ STIE Ichsan Pohuwato Gorontalo, Jl. Trans Sulawesi No. 47 Marisa Pohuwato \\ E-mail: misrahsosimm@gmail.com
}

Prof. Dr. Muhammad Ali, SE., MS.

Professor of Economic, Graduate School of Economics Hasanuddin University, Makassar South Sulawesi, Indonesia

Prof. Dr. Abdul Rakhman Laba, SE., M.BA.

Professor of Economic, Graduate School of Economics Hasanuddin University, Makassar South Sulawesi, Indonesia

\author{
Dr. H. Muh. Sobarsyah, SE., M.Si.
}

Ph.D of Economics, Graduate School of Economics Hasanuddin University, Makassar South Sulawesi, Indonesia

DOI: $10.31364 / S C I R J / v 6.16 .2018 . P 0618536$

http://dx.doi.org/10.31364/SCIRJ/v6.i6.2018.P0618536

\begin{abstract}
This study aims to develop and analyze the effect of ownership structure on dividend policy and firm value on manufacturing companies listed on Indonesian stock exchanges. The result showed that managerial ownership variable to dividend policy had positive and significant effect of 3,005 with $t$ value 0,617 with standard of error 4,874 at significance level 0,537 and company value equal to 0,048 with value $t$ equal to 1,079 with standard of error (SE) 0.045 at significance level of 0.281 . The institutional ownership of the dividend policy had negative effect of -1.497 with the value of $t$ equal to $\mathbf{- 2 . 9 8 1}$ with the standard of error 0,502 at significance level 0,003 and at company value equal to 0,064 with $t$ value equal to 2,990 with standard of error 0,21 at significance level 0.003. While dividend policy to firm value have positive and significant effect equal to 0,025 with $t$ value equal to 37,398 with standard of error 0,001 at 0.000 significance level.
\end{abstract}

Keyword: ownership structure, dividend policy and value company.

\section{PRELIMINARY}

The normative purpose of corporate financial management is to increase the value of the company, which is reflected in the market price of its shares (Qureshi, 2006). Increasing company value means maximizing the wealth or welfare of shareholders (Martin, et al, 1994). The company's objectives can be achieved through the implementation of the financial management functions carefully and appropriately, as any financial decisions taken will affect other financial decisions that impact corporate value (Jensen and Smith, 1994) The company's financial management concerns the settlement of important decisions taken by the company, including investment decisions, funding, and dividend policy. An optimal combination of the three decisions will maximize the value of the firm, thus the decision of the decision is interrelated with each other (Qureshi, 2006)

The modern organization and corporation theory of Marshal 1920, in Berle and Means, 1933) has been widely applied in large and modern corporations to date. This theory states that within an organization there must be a strict separation between control activities and operational activities, in this case there must be a separation between the Board of Directors as a representation of shareholders exercising control over the company's operations and the Board of Management-CEO as a party running the company's operations. Further development, agency theory states that companies that separate management functions with ownership functions will be susceptible to agency conflict (Jensen and Meckling, 1976). This is due to the separation of roles between shareholders as principals and managers as agents, hence managers will ultimately have significant controlling rights in terms of how they allocate investor funds (Jensen and Meckling, 1976; and Shleifer and Vishny, 1986). The basic assumption in 
agency theory is that managers will act opportunistically by taking advantage for personal gain before meeting the interests of shareholders.

Eisenhardt (1989) states that agency theory uses three assumptions of human nature: (1) human beings in general selfishness (self interest); (2) human beings have limited thinking about the bounded rationality; and (3) humans always avoid risk (risk averse). Based on the assumptions of human nature, managers as human beings will act opportunistic, which will give priority to his personal interests. Correspondingly, Gitman (2000) argues that control of modern firms is often in the hands of non-owner professional managers, there is a separation between the owner and the manager. Generally, financial managers will agree with the maximization goals of the welfare of the owner. But the reality in practice, however, the manager is also concerned with his welfare, job security, his lifestyle and other pleasures such as being a member of golf clubs, luxury vehicles, luxurious and comfortable offices and others. Such interests make managers do not want to take a greater risk, because it will disrupt his position and damage his personal well-being. As a result of the conflict between the two interests, profits can be not maximum and potentially harmful to the welfare of the owners of the company.

Managerial opportunism hypothesis as expressed by Jensen (1986), states that managers have a tendency to hold cash, provide them to consume more extra income, use in building empires, and invest in projects and incomes that may enhance their personal pride but not beneficial to shareholders (Jiraporn and Ning, 2006).

Furthermore, agency theory states that agency problem can be overcome by doing some control mechanism one of them is by increasing dividend payout ratio, which will result in not enough free cash flow and management is forced to seek funding from outside to finance its investment (Crutchley and Hansen, 1989). Rozeff (1982) argues that dividend payout is one way to reduce agency cost of equity because the conflict between management and shareholders will decrease. Dividend payouts show that management manages the company well and can be a positive signal for shareholders to reinvest in the company. Rozeff (1982) and Easterbrook (1984) explain that dividend payments will reduce the sources of funds controlled by managers, thereby reducing managerial power and making dividend payouts similar to capital market monitoring that occurs when firms acquire new capital from external parties, agency costs.

Dividend payments are understood to reduce agency issues, but research that discusses the direct relationship between dividends and corporate value in this case the shareholders' prosperity to date is still ambiguous (Jensen and Smith, 1984). Miller and Modigliani (1961) argue that with perfect market assumptions, rational behavior and perfect certainty, finding the relationship that corporate value and dividend policy are irrelevant. The results of Black and Scholes (1974), Jose and Stevens (1989) studies support the dividend irrelevant theory argument. However, in actual market practices, it is found that dividend policy appears to be a problem, and loosening one or more of the assumptions of perfect capital market assumptions is as a basis for the formation of theories that counter the theory of dividend policy.

By distributing dividends the company considers the proportion of share between payments to shareholders and reinvestment within the company. On the one hand, retained earnings is one of the funding sources for the growth of the company, but on the other hand dividend is a cash flow or asset that will be distributed to shareholders so that in deciding a dividend policy requires a very mature consideration (Barclay, 1988)

\section{Formulation of the problem}

Based on the above mentioned problems in order to support empirical research, some researches are proposed to be developed in this study, as follows:

1. Does the share ownership structure directly and indirectly affect corporate value through dividend policy

2. Does dividend policy directly and indirectly affect corporate value through dividend policy?

\section{BASIS THEORY AND HYPOTHESES AND HYPOTHESES}

\section{Share Ownership Structure}


Theory of financial management has proven that share ownership will affect the value of the company. This at once broke the old paradigm that says otherwise. Early theoretical and empirical evidence has been shown by Berle and Means (1933) in Navissi and Naiker (2006); and Jensen and Meckling (1976), who found evidence that corporate value is a function of distribution with a certain proportion of ownership by insiders and outsiders. . The results of this study were further supported by Navissi and Naiker (2006) and found evidence that single and dominant ownership (blockholder) had a significant effect on firm value. In this case Holdemeess and Sheehan (1988) specifically find a significant positive effect of blockholder on stock returns in the stock market. In addition to stock returns, some studies attempt to use proxies based on accounting based values as a measure of corporate value. Navissi and Naiker (2006); Jensen (1993) found that the higher the ownership of insiders the higher the firm value, which is shown by the higher value of Tobin's q.

Institutional theory (agency theory) raises an argument against a conflict between the owner of the shareholder with the manager. The conflict arose as a result of different interests between the two parties. Managerial ownership or insider ownership is then seen as an appropriate control mechanism to reduce the conflict. In this case the ownership of the insider is considered to equalize the interests between the owner and manager, so the higher the insider ownership will be the higher the value of the company. Shleifer and Vishny (1986) and Allen, Bernardo, and Welch (2000) argue that large institutional investors are more willing and able to monitor corporate management than smaller institutional investors and scattered ownership. Agrawal and Mandelker (1990) argue that institutional investors have an important role as external overseers in the stock market. They also argue that institutional investors provide meaningful oversight services and act as a barrier to the opportunistic behavior of corporate managers. In terms of managerial ownership, Shleifer and Vishny (1986) argue that large shareholdings in terms of economic value have an incentive to monitor

The ownership structure can be explained from two points of view (Iturriaga and Sanz, 2000) ie agency approach and asymmetric information approach. The agency approach considers the ownership structure as an instrument to reduce conflicts of interest among various claims holders. The asymmetric information approach sees ownership structure as a way to reduce information imbalance between insiders and outsiders through disclosure of information in capital markets (Leland and Pyle, 1997).

\section{Dividend Policy}

The residual dividend theory states that when the firm will decide how much cash it should share, there are two things to keep in mind: (1) the main objective is to maximize shareholder value, and (2) the resulting cash flow the company belongs to shareholders (Brigham and Houston, 2006). Management should refrain from retaining earnings unless such profits can be reinvested in order to generate higher returns that shareholder feel as well as shareholders gain if they invest the money in risky investments. Thus, internal equity, retained earnings, lower capital costs than external equity (ordinary shares). This condition encourages companies to retain earnings as it adds to the base of internal equity and thereby reduces the likelihood that firms should add external equity in the future to fund their investments.

New stock issuance costs accentuate the difference between internal and external capital. Without the cost of issuance, the company will not struggle to determine how much dividends and how much profit is held, as well as how much external funding is. With the cost of the issuance, the company will obviously prioritize internal funding. Consequently, the company will make a dividend payment after investment funds are met; in other words, only if there is "residual income" or residual income then the dividend will be paid. This is the essence of the theory of residual dividend or residual dividend theory.

\section{The value of the company.}

The normative purpose of corporate financial management is to increase the value of the firm, which is reflected in its stock market prices (Wright and Ferris, 1997; Walker 2000; and Qureshi, 2006). Increasing company value means maximizing the wealth or welfare of shareholders (Martin, et al., 1994). The objectives of the company can be achieved through the 
implementation of the financial management functions carefully and appropriately, since any financial decisions taken will affect other financial decisions that impact corporate value (Jensen and Smith, 1994; Fama and French, 2002). The company's financial management concerns the settlement of important decisions taken by the company, including investment decisions, funding, and dividend policy. An optimal combination of these three decisions will maximize the value of the firm, thus the decision of the decision is interrelated with each other (Qureshi, 2006).

The modern organization and corporate theory of Marshal (1920, in Berle and Means, 1933) has been widely applied in large and modern corporations to date. This theory states that within an organization there must be a strict separation between control activities and operational activities, in this case there must be a separation between the Board of Directors as a representation of shareholders exercising control over the company's operations and the Board of Management-CEO as a party running the company's operations. Further development, agency theory states that companies that separate management functions with ownership functions will be susceptible to agency conflict (Jensen and Meckling, 1976). This is due to the separation of roles between shareholders as principals and managers as agents, hence managers will ultimately have significant controlling rights in terms of how they allocate investor funds (Jensen and Meckling, 1976; Eisenhardt, 1989; and Shleifer and Vishny, 1997). The basic assumption in agency theory is that managers will act opportunistically by taking advantage for personal gain before meeting the interests of shareholders.

Managerial opportunistic behavior in relation to the achievement of corporate value, can be described through the functions of corporate financial management, namely the function of investment, financing function, and function in running the dividend policy. Jensen (1986) argues that managers in public companies have an incentive to expand beyond the optimal size, even though the expansion is done on projects with negative net present value (NPV). Overinvestment condition is done by using internal funds generated by the company in the form of free cash flow. The problem of free cash flow refers to the activities of managers who prefer investing (albeit with negative NPV) rather than dividing it into dividends. Managers are interested in investing in order to increase growth and decrease corporate risk through diversification, although this may not always improve shareholder wealth, Bethel and Julia (1993). The results of Grand Jammine and Thomas's study, as cited by Bethel and Julia (1993), suggest that managers of public companies tend to expand and diversify companies, even if they do not increase the value of firms.

Managerial opportunism hypothesis as expressed by Jensen (1986), states that managers have a tendency to hold cash, provide them to consume more extra income, use in building empires, and invest in projects and incomes that may enhance their personal pride but not beneficial to shareholders (Jiraporn and Ning, 2006). In addition, managers also have a tendency to use high debt not on the basis of maximization of corporate value, but for their opportunistic interests. This will result in loan interest expense and corporate bankruptcy risk increase, as the agency cost of debt is higher. Increased agency costs will ultimately affect the decline in corporate value. Thus, the managerial opportunistic behavior does not create or increase the value of the company, but instead will damage or decrease the value of the company.

Based on the problems studied, the authors draw a hypothesis is "highly suspected influence of ownership structure (X1) and dividend policy (X2) on firm value through managerial opportunistic behavior in manufacturing companies listed on Indonesia Stock Exchange.

\section{Method Approach}

The approach used in this research is quantitative approach (positivis). Positivist approach is a thinking approach that has characteristics such as the following: (1) memetingkan the position of theory in mebangun piker and hypothesis. (2) focusing on the answer about the presence or absence of relationships between variables. (3) using quantitative data and analysis tools. (4) the result to make a generalization (deductive). With this positivist approach we need numerical data to be analyzed using statistics to test a number of hypotheses. 
This type of research includes explanatory research that is, whether or not the influence can be known through hypothesis testing which results can be used to explain the relationship.

\section{Data analysis method}

In this study using path analysis to analyze the pattern of relationship between variables with the aim to determine the direct or indirect influence of a set of independent variables (Eksogen) to the dependent variable (endogenous). The underlying assumption of path analysis is, (1) The relationship between variables is linear, adaptive and normal. (2) only a causal flow system in one direction, meaning no direction of causality is reversed. (3) the dependent variable (endogenous) is minimal in the scale of interval and ratio size. (the model in the analysis is correctly identified based on relevant theories and concepts) means the model being studied or constructed based on a particular theoretical framework that is able to explain the causal relationship between the variables studied.

\section{Population and Sample}

The population in this study is a manufacturing company listed on the Indonesia Stock Exchange, as contained in the Indonesian Capital Market Directory (ICMD). Companies selected as samples in this study are manufacturing companies listed on the Indonesia Stock Exchange which publish financial statements as of December 31 and have audited financial statements, (2) Available data on percentage of shares owned by managerial company (3) Available data about the percentage of shares owned by the institution (institutional investors), (4) the company divides the dividends seen from the Dividend Payout Ratio (DPR), (6) the company has information related to the measurement of Tobin's Q variable. The data taken are panel data that combine data time series for 7 years and cross section data from 122 sample companies.

\section{Results and Discussion}

\section{Descriptive Analysis}

Analysis and Testing Structural Model Influence Ownership Structure to Company's Dividend and Value Policy

In the previous discussion it has been argued that this study is to investigate the effect of ownership structure that includes: sahan ownership and managerial ownership of dividend policy and corporate value.

1. Managerial ownership (X1) on dividend policy (Y1) The coefficient of variable influence of Managerial Ownership Structure (X1) on Dividend Policy (Y1) is 3,005 with t value equal to 0,617 with standard of Error (SE) equal to 4,874 at significance level 0.537. Statistical value t arithmetic influence of Managerial Ownership Structure (X1) on Dividend Policy (Y1) of 3.005 with a significance of 0.537 or above 0.05. This means the Managerial Ownership Structure (X1) has a positive and insignificant effect on the Dividend Policy (Y1).

2. Managerial Ownership Structure (X1) to Company Value (Y2) The coefficient of variable influence of Managerial Ownership Structure (X1) to Company Value (Y2) is 0,048 with value t equal to 1,079 with standard of Error (SE) equal to 0,045 at significance level 0,281. The coefficient shows that the variable of Managerial Ownership Structure (X1) has a positive effect on Corporate Value (Y2). This means that an increase in Managerial Ownership Structure (X1), will be followed by an increase in Corporate Value (Y2) with the assumption that other factors affecting the size of Company Value (Y2) are considered constant. Statistical value t arithmetic influence of Managerial Ownership Structure (X1) to Company Value (Y2) of 1.079 with significance of 0.281 or above 0.05. This means the Managerial Ownership Structure (X1) has a positive and insignificant effect on Corporate Value (Y2).

3. Institutional ownership (X2) on dividend policy (Y1) The coefficient of influence of institutional ownership variable (X2) on Dividend Policy (Y1) is $-1,497$ with t value equal to $-2,981$ with standard of error 0,502 at significance level 0,003. The coefficient indicates that the institutional ownership variable (X2) negatively affects the Dividend Policy (Y1). This means that an increase in the proportion of institutional ownership (X2), will be followed by a decrease in the Dividend Policy (Y1) with the assumption that other factors affecting the size of the Dividend Policy (Y1) are considered constant. The statistical 
value $t$ arithmetic influence of institutional ownership (X2) on Dividend Policy (Y1) is -2,981 with significance 0,003 or below 0,05. This means institutional ownership (X2) has a negative and significant effect on the Dividend Policy (Y1).

4. Institutional Ownership (X2) to Company Value (Y2) The coefficient of influence of institutional ownership variable (X2) to Company Value (Y2) is 0,064 with t value equal to 2,990 with standard of Error (SE) equal to 0,021 at significance level 0,003. The coefficient indicates that the institutional ownership variable (X2) has a positive effect on Corporate Value (Y2). This means that an increase in the proportion of institutional ownership (X2), will be followed by an increase in Corporate Value (Y2) with the assumption that other factors affecting the size of Company Value (Y2) are considered constant. Statistical value $t$ arithmetic influence of proportion of institutional ownership (X2) to Company Value (Y2) equal to 2,990 with significance 0,003 or under 0,05 . This means institutional ownership (X2) has a positive and significant effect on Corporate Value (Y2).

5. The dividend policy (Y1) to Corporate Value (Y2) The coefficient of influence of Dividend Policy variable (Y1) to Company Value (Y2) is 0,025 with value of t equal to 37,398 with standard of Error (SE) equal to 0,001 at significance level 0,000. The coefficient shows that the variable of Dividend Policy (Y1) has a positive effect on Corporate Value (Y2). This means that an increase in the Dividend Policy (Y1), will be followed by an increase in Corporate Value (Y2) with the assumption that other factors affecting the size of the Company Value (Y2) are considered constant. The statistical value $t$ arithmetic influence of Dividend Policy (Y1) to Company Value (Y2) is 37,398 with significance 0.000 or below 0,05. This means Dividend Policy (Y1) has a positive and significant effect on Corporate Value (Y2)

As for the large influence of variables in the show in the following figure:

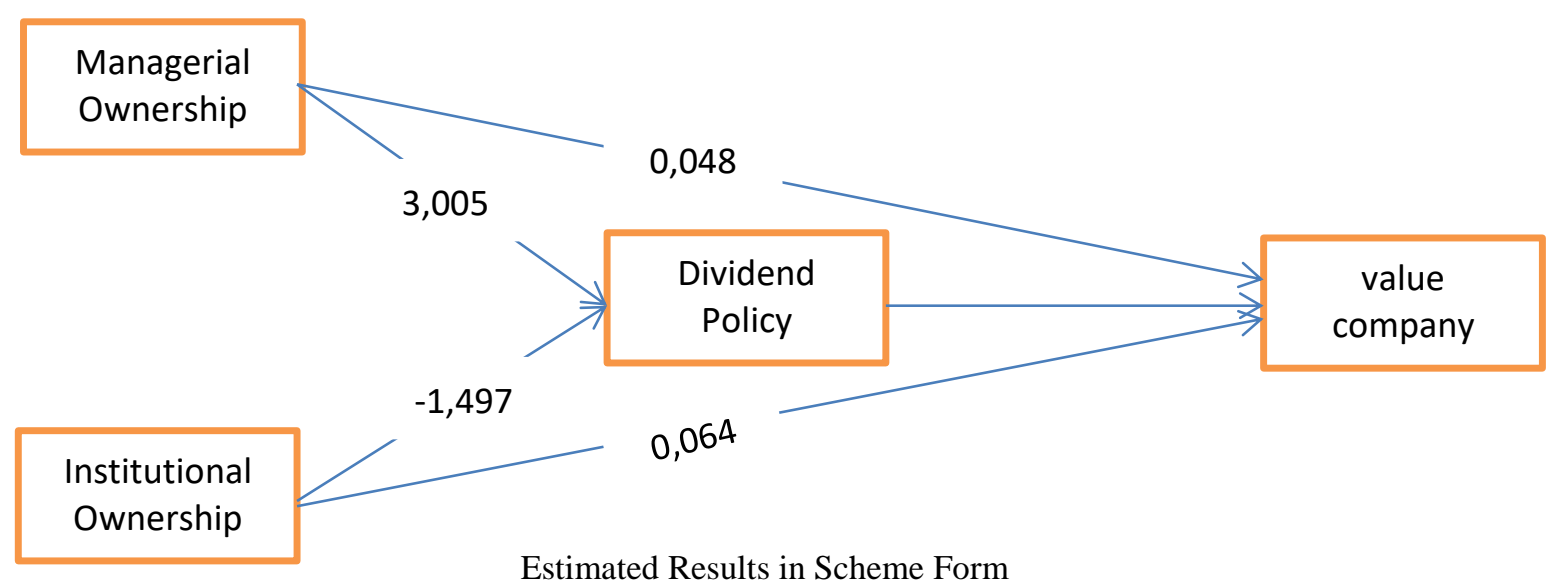

\section{DISCUSSION}

\section{Effect of Stock Ownership Structure variable to Dividend Policy}

The test result shows the variable of Ownership Structure of Stock does not have an effect on Dividend Policy. The results of this study are in line with Bradford (2007) research, that minority ownership does not have the power or control to shareholders to determine the dividend policy (which determines the RPUS), which is dominated by majority shares. In addition, this result is because during the period 2005 - 2012 more than 50\% of sample companies did not distribute dividends in a row. So that the ups and downs of the managerial ownership structure does not significantly affect the dividend policy. However, the results of this study do not coincide with Eckbo and verma (1994) which empirically show that dividends decrease by increasing the strength of managerial ownership and also argue that in managers of controlled firms in which they have absolute power. Chen et al (2005) also shows a negative relationship between management and dividend policy ownership and further argues that management 
ownership is negatively related to firm performance in Hong Kong. In general, managers get a chance to engage in share ownership with the intention of putting together with shareholders. Through this policy managers are expected to produce good performance and direct dividends at a low level. With the determination of low dividends the company has high retained earnings that have a relatively high internal funding source to finance future investment. Based on these results so that Hypothesis 2 that there is a negative and significant influence Capital structure on dividend policy is accepted, while the negative and significant influence of the structure of Managerial Ownership of Dividend Policy is rejected.

\section{The Influence of Managerial Ownership To Company Value}

The test results show that the Managerial Ownership Structure has no significant effect on Corporate Value, the result of this study in accordance with the research of Sujoko and Soebiantoro (2007) finds evidence that Managerial Ownership has no effect on Corporate Value. This may be because the company's management has no control over the company. Moreover, the average ownership of management shares is only 3.8\%. Management is controlled by majority owner, so management is only as an extension of majority ownership in the effort to increase the Company Value. (Adnantara, 2013). This result is due to an increase in the managerial ownership structure unable to raise the company's value proxied by tobinsQ. In contrast to Jensen and Meckling, (1976). Increasing the shares owned by managers through managerial ownership will motivate the performance of management because they feel they have a share in the company both in decision making and responsible for the decisions taken due to participate as a shareholder of the company so that the better management performance and influence the increase in corporate value. Managerial ownership (insider ownership) is measured in proportion to managerial share ownership (Iturriaga, et al., 2001).

\section{Effect of Dividend Policy on Corporate Value}

The effect of Dividend Policy variable on Corporate Value is positive and significant. this means that an increase in Dividend Policy will be followed by an increase in Corporate Value with the assumption that other factors affecting the size of the Dividend Policy are considered constant. The company's ability to pay dividends can reflect the value of the company. If the dividend payout is high, then the stock price is also high which affects the high value of the company and vice versa (Aliahmed, 2008). Thus, dividend policy is one of the most important decisions (Murekefu and Ochuodho, 2012). Okpara (2012) explains the concerns faced by firms in dividend policy is how much revenue can be paid as dividends and how much can be sustained, because sometimes the dividend payout for some investors is not a positive signal. Investors assume that corporate managers are not sensitive to investment opportunities that will be profitable but prefer to pay dividends. Thus, the value of the company may decrease due to the lack of willingness of shareholders to invest in the company.

Some studies that are not in line with the results of this study are the theories put forward by Miller and Modigliani who argue that the dividend policy does not affect the value of the company because according to them the dividend payout ratio is only the details and does not affect the welfare of shareholders (Boanyah, et al. Increasing the value of dividends is not always accompanied by an increase in the value of the firm because the value of the company is determined only by the ability of the company to generate profits from the company's assets or investment policy (Mardiyanti, dkk 2012). Similar results were also found by Gill, et al. (2011), Guizani and Ezzeddine (2012), Jiang and Comain (2013). These results fit the theory according to Brealey, Myers and Marcus (2008) that, "As investors do not need dividends to convert their shares into cash, they do not will pay a higher price for the company with higher dividend payouts.

Implications of research results for investors that the company's ability to pay dividends can reflect the value of the company. If the dividend payout is high, then the stock price is also high which affects the high value of the company and vice versa. Thus, dividend policy is one of the most important decisions. The implications of the research results for the managers of the company that by distributing dividends to shareholders will give a positive signal for other investors so that the investor interest to invest increases and the value of the company also increased Implication of research results for researchers that the results of this study in line with the Bird-In-The Theory -Hand is a theory that explains that investors want high dividend payouts. 
The reason often raised in choosing Bird-In-The-Hand Theory is because there is a presumption that getting high dividends at this time the risk is less than the capital gains in the future. One of the advantages when applying Bird-In-The-Hand Theory is to provide high dividends, then the stock price of the company will also be higher too.

\section{CONCLUSION}

Based on the problems that exist in the research, research hypotheses as well as the results of data analysis and discussion of research results, it can be drawn conclusions as follows:

Managerial ownership and institutional ownership variables have a negative and significant influence on dividend policy but positively affect the value of this company indicates that when the proportion of managerial and institutional ownership increases it will be followed by decrease dividend payout but will increase company value.

\section{DAFTAR RUJUKAN}

Agrawal, A., dan G. Mandelker (1990), "Large shareholders and the monitoring of managers". Journal of Financial and Quantitative Analysis, Vol. 25, No. 2 pp. 143 - 161.

Allen, F., Bernardo, A. E \& Welch, I. 2000. A Theory of Dividends Based on Tax Clienteles. The Journal of Finance. Vol. 55, No. 6, pp: 2499-2536.

Barclay, M. J., dan C. W. Smith, Jr. (1988), "Corporate Payout Policy: Cash Dividends versus Open-Market Repurchases". Journal of Financial Economics, Vol. 22, pp. 61-82.

Berle, Adolf, dan Gardiner Means (1932), “The Modern Corporation and Private property”. Mac-Millan, New York.

Bethel, J.E. dan Julia Liebeskind (1993), “The Effect of Ownership Structure on Corporate Structuring”. Strategi management Journal, Vol. 14: pp. $15-31$.

Black, F., dan Scholes, M. (1974), The effects of dividend yield and dividend policy on common stock prices and returns. Journals of Financial Economics, Vol. 1: pp. 1-22.

Boanyah, Ebenezer Adu, Desmond Tutu Ayentimi and Osei Yaw Frank. 2013. Determinants of Dividend Payout Policy of Some Selected Manufacturing Firms Listed on The Ghana Stock Exchange. Journal of Finance and Accounting, 4(5): pp: 49-60

Brealey, R. dan S. Myers (2008), Principles of Corporate Finance, 8th edn. London: McGraw-Hill.

Brigham, Eugene F. dan Houston Joel F. (2006), "Dasar-Dasar Manajemen Keuangan Jilid 1". Alih Bahasa Ali Akbar Yulianto, Edisi Kesepuluh, Penerbit Salemba Empat, Jakarta.

Crutchley, C.E dan R. Hansen (1989), “A Test of Agency Theory of Managerial Ownership, Corporate Leverage, Corporate Dividends”. Financial Management, Vol. 18; pp. 35-57.

Easterbrook, F. H. (1984), "Two AgencyCost Explanations of Dividends". American Economic Review, Vol. 74: pp. 650-659.

Eckbo B. Espen, Savita Verma, 1994, Managerial Share Ownership, Voting Power, and Cash Dividend Policy, Journal of Corporate Finance1 : 33-62

Eisenhardt, K. M., 1989. Building Theories from Case Study Research, Academy of Management Review, vol. 14, no. 4, pp 532550 ,

Fama, E. F., dan K. R. French (2002), “Testing Trade-Off and Pecking Order Predictions About Dividends and Debt.” Review of Financial Studies, Vol. 15: pp. 1-33.

Gitman, L.J, 2000, "Principle of Management Finance," 9th d, Addison Wasler, Massachussets.

Guizani, Moncef and Ezzeddine Abaoub. 2012. Does The Contribution Of Dividend To Firm Value Depend On Controling Shareholders ?. International Journal Of Disclosure and Governance, 9(1): pp:6277

Holderness, C.G., dan Sheehan, D.P. (1988), “The role of majority shareholders in publicly held corporations: An exploratory analysis". Journal of Financial Economics, Vol. 20: pp. 317-40.

Iturriaga, Felix J. Lopez dan Sanz, Juan Antonio Rodiguez (2000), “Ownership Structure, Corporate Value and Firm Investment: A Spanish Firms. 
Iturriaga, Lopez, Felix J., Rodriguez Sanz, and Juan Antonio. 2001. Ownership Structure, Corporate Value, and Firm Investment: A Simultaneous Equations Analysis of Spanish Companies. Journal of Management \& Governance, 5(2): p:179-204 Simultaneous Equations Analysis”. Direction General de Ensenanza Superior e Investigacion Cientifica.

Jensen, Michael C. (1986), "Agency Costs of Free Cash Flow, Corporate Finance, and Takeovers", American EconomicReview. Vol. 76: pp. 23-329

Jensen, Michael C. dan William H. Meckling. (1976). Theory of the Firm: Managerial Behavior, Agency Costs and Ownership Structure. Journal of Financial Economics, 3(4), 305-360.

Jensen, Michael C., dan Smith, Jr Clifford W. (1994), "The Modern Theory of Corporate Finance”. Mc Graw - Hill Book Company.

Jiang, Jun and Komain Jiranyakul. 2013. Capital Structure, Cost Of Debt And Dividend Payout of Firms in New York And Shanghai Stock Exchanges. International Journal Of Economics and Financial Issues, 3(1): pp:113-12

Jiraporn, Pornsit, dan Yixi Ning (2006), "Dividend Policy, Shareholder Rights, and Corporate Governance”. Journal of Applied Finance - Fall/winter 2006.

Jose, M.L., dan J.L. Stevens (1989), “Capital Market Valuation of Dividend Policy”. Journal of Business Finance \& Accounting, Vol. 16: pp. 651-662.

Leland, Hayne E. dan David H. Pyle. (1997). Informational Asymmetries, Financial Structure, and Financial Intermediation. The Journal of Finance, 32(2), 371387

Martin, John D., Keown, Arthur J., Petty, J. William, dan Scott, Jr., David F. (1994), “Dasar-Dasar Manajemen Keuangan”. Edisi Kelima, Raja Grafindo Persada, Jakarta.

Miller, M. H., dan F. Modigliani (1961), "Dividend Policy, Growth, and the Valuation of Shares". Journal of Business, Vol. 34: pp. 411-433

Murekefu, Timothy Mahalang'ang'a and Ochuodho Peter Ouma. 2012. The Relationship Between Dividend Payout and Firm Performance : A Study of Listed Companies in Kenya. European Scientific Journal, 8(9): pp: 199-215

Navissi, F., dan Naiker, V. (2006), "Institutional ownership and corporate value”. Managerial Finance, Vol. 32, No. 3: pp. 247256.

Okpara, Godwin Chigozie. 2012. AsyModiglani dan Milleretric Information And Dividen Policy in Emerging Markets : Empirical Evidence From Nigeria. International Journal Of Economics And Finance, 2(4): pp:212-220

Qureshi, Muhammad Azeem (2006), “System dynamics modelling of firm value”. Journal of Modelling in Management. Vol. 2, No. 1, pp. 24-39

Rozeff, M. S. (1982), "Growth, Beta, and Agency Costs as Determinants of Dividend Payout Ratios". Journal.

Shleifer, A. dan R.W. Vishny (1986), “Large Shareholders and Corporate Control,” The Journal of Political Economy 94, 461488.

Sujoko dan Soebiantoro, Ugy. 2007. Pengaruh Struktur Kepemilikan Saham, Leverage, Faktor Intern dan Faktor Ekstern terhadap Nilai Perusahaan (Studi Empirik pada Perusahaan Manufaktur dan Non Manufaktur di Bursa Efek Jakarta), Jurnal Manajemen dan Kewirausahaan. Vol 9: Hal. 41-48.

Sujoko dan Soebiantoro, Ugy. 2007. Pengaruh Struktur Kepemilikan Saham, Leverage, Faktor Intern dan Faktor Ekstern terhadap Nilai Perusahaan (Studi Empirik pada Perusahaan Manufaktur dan Non Manufaktur di Bursa Efek Jakarta), Jurnal Manajemen dan Kewirausahaan. Vol 9: Hal. 41-48.

Walker, M Mark (2000), "Corporate Take Over, Strategic Objectives, and Acquiringn Firm Shareholders Wealth". Financial Management, Winter: pp. 36-46.

Wright, Peter, dan Ferris, Stephen P. (1997), ”Agency Conflict \& Corporate Stategy: The Effect of Divestment on Corporate Value”. Strategic Management Journal. Vol. 18: pp. 77-83. 